\title{
Sustainable tourism within an eco-city context: analytical study for the master plan of Siwa City, Egypt
}

\author{
M. M. Salem \& H. El-Shimy \\ Department of Architecture, Faculty of Engineering, \\ Pharos University in Alexandria, Egypt
}

\begin{abstract}
Many urban areas now face an increasing population with growing middle class expectations and increasing numbers of interregional and domestic tourists. These urban areas face competition from a wide range of destinations for the tourist's dollar and the investment necessary to develop world-class facilities. The nature of the tourist is changing very quickly making planning and management evermore a challenge. Many of the tourists are in fact first time visitors while others are from a younger generation of travellers with quite different expectations than their parents. There is also the recognition of the need to meet the needs of multiple cultures with their diverse lifestyles, religious beliefs and traditions.

Given the rapid rise of tourism there has been a clear pattern of increased air pollution caused by the intensive use of vehicles for tourism/recreation-related mobility, pollution of water and marine ecosystems due to recreational navigation and peaks in the generation of solid and liquid wastes. It has been documented that tourism facilities are responsible for substantial increases in the consumption of fossil fuels for heating and electricity due to the visitors' rising quality expectations for services and facilities. Poorly planned and managed tourism destinations disturb birds feeding habitats and wildlife, cause land erosion and damage to vegetation which leads to erosion in ecologically sensitive areas. In summary while tourism can significantly increase the quality of life for its residents it also brings about significant disruption.
\end{abstract}


Determining the criteria for the sustainable tourism and measuring the degree of its sustainability in the urban societies are important issues in this area.

Keywords: sustainable, tourism, eco-city, investment, measuring, criteria, urban, planning, Siwa.

\section{Introduction}

Most eco-city concepts have been developed to deal specifically with resident needs and activities and protecting environmental values. However, developing the eco-city concept becomes much more complex when many cities are faced with the challenge of meeting the needs and aspirations of tourists which introduces a number of new stakeholders to be involved in the overall planning and development process.

\section{Tourism}

Tourism with the annual income of about 1000 billion dollars in the world is one of the most important phenomena of the present century which in addition to removing poverty, expanding justice, and creating employment produces a high income and creates jobs for the poor people [2]. This industry which is the third important industry in the world after oil and automobile-making industries is an important element in advancing the social and cultural purposes in addition to its role in improving economic aspects and undoubtedly it's most significant effect is the closeness of human communities via cultural exchanges. Meanwhile, those countries with tourist attractions regarding the natural scenery, culture and the ancient civilization and historical and religious works possess good talents and capabilities in attracting the tourists. They can earn billions of dollars each year by an appropriate investment in different parts of this industry and retaining their place in the world.

In the 21st century, tourism is about to affect many of the geographical places and create a new spatial model in the different geographical areas.

In the present years, the sustainable development is introduced as a new method to be used by societies in order for them to think about the level of life, the social justice, and perseverance of the resources [3]. The expansion of the sustainable tourism is very essential due to its importance and the potential positive and negative economic, social, cultural, political, and environmental effects that it may have.

\section{The eco-city concept}

The Eco-city is an umbrella concept that encompasses a wide range of approaches that aim to make existing cities and urban development more ecologically sound and liveable (Jabaroon 2006). These approaches introduce a number of environmental, social and institutional policies that are directed towards sustainable solutions. The concept mainly promotes the ecological 
agenda and emphasizes environmental management through a set of institutional and policy tools. According to Register (2002), eco-city zoning is a tool for polycentric restructuring of car-dependent cities by increasing the density around centres and recovering natural and agricultural landscape in the interspaces. It strongly focuses on a scale of ecosystems and habitats dedicated to the minimization of inputs of energy, water and food, and waste output. Generally, an eco-development strives for a carbon-neutral footprint where the human habitat is designed as a closed system. May (2008: 1) suggest that:

In an eco-city, human habitat is designed with the recognition that the city, as the earth, is a closed system. When a thing ends its life cycle in a place in which it is treated as waste, it is polluting a closed system that will eventually become too full of detritus to support life.

\section{Eco-tourism}

Tourism has moved from a process of mass movement of people to people traveling with a wide range of motivations. The public and private sector response has taken many forms, but heritage and its many dimensions and nature-based activities are still seen as the primary reasons why people travel.

One important tourism niche market is the eco-tourism. In many areas of activity the trend has been to apply the prefix "eco" to a number of activities which often are by no means sustainable in any significant dimension. The same is true of tourism where many stakeholders have now identified nature-based activities as eco-tourism. However, eco-tourism has a very specific meaning. The International Eco-tourism Society defines eco-tourism as a "responsible travel to natural areas that conserves the environment and improves the well-being of local people" (TIES 1990). The Society states that eco-tourism is about "uniting conservation, communities, and sustainable travel". This means that those who implement and participate.

\subsection{Eco-tourism indices}

In the present research, to assess the achievement of eco-tourism in urban societies, one of the most complex formulas which is in relation with the essential needs of the tourists is employed. To do so, a list of the tourists' human needs is suggested as a basis for collecting a set of tourism indices. These indices are obtained from the completed questionnaires by tourists and the study of the tourists' requirements to identify and classify the needs of these people and coordinating them with the sustainable development factors (Table 1).

These indices depict the attempt to synthesize the current information about the environment and tourism and to help better understanding of the relationship between the completion of the tourist's activities, its environmental effects and finally the group and individual policies relating to them. 
Table 1: Eco-tourism indices in urban societies (source: research findings).

\begin{tabular}{|c|c|c|c|c|}
\hline The Assessment IndeX & $\begin{array}{l}\text { Weight of } \\
\text { Realms }\end{array}$ & Realms & $\begin{array}{c}\text { Weight of } \\
\text { Classes }\end{array}$ & Class \\
\hline $\begin{array}{l}\text { Number and types of the public } \\
\text { transport fleet/ number of } \\
\text { vehicles allocated to tourists/ } \\
\text { number of subway stops, bus } \\
\text { stops, etc. }\end{array}$ & $\mathrm{B}_{1}$ & Transport & \multirow{7}{*}{$\mathrm{A}_{1}$} & \multirow{7}{*}{ 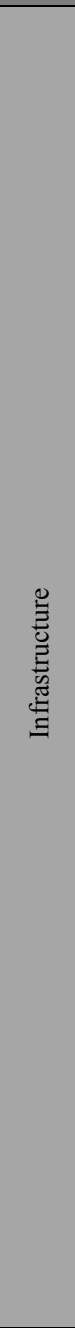 } \\
\hline $\begin{array}{l}\text { Distance from the intercity ways } \\
\text { and transit routes/ different kinds } \\
\text { of existing ways involving } \\
\text { railways, air routes, subway/ } \\
\text { distance from the airports to the } \\
\text { urban non-residential areas. }\end{array}$ & $\mathrm{B}_{2}$ & The way network & & \\
\hline $\begin{array}{l}\text { Number of the hotels under the } \\
\text { environment protection systems/ } \\
\text { number of the tourist service } \\
\text { centres/ number of restaurants/ } \\
\text { the allocated budget to the } \\
\text { tourism activities/ total tourism } \\
\text { cost per year/ employment in } \\
\text { hotels and restaurants/ } \\
\text { percentage of tourism } \\
\text { population. }\end{array}$ & $\mathrm{B}_{3}$ & Tourism centres & & \\
\hline $\begin{array}{l}\text { Amount of coordination with the } \\
\text { universal electronic bank } \\
\text { services/ amount of bank } \\
\text { facilities to support tourism } \\
\text { development }\end{array}$ & $\mathrm{B}_{4}$ & Bank Services & & \\
\hline $\begin{array}{l}\text { Number of health-care centres } \\
\text { (clinic)/ number of people } \\
\text { suffering from dangerous and } \\
\text { contagious diseases/ amount of } \\
\text { the environment pollution. }\end{array}$ & $\mathrm{B}_{5}$ & Health & & \\
\hline $\begin{array}{l}\text { Degree of flexibility of the local } \\
\text { rules concerning tourism/ } \\
\text { satisfaction from issuing visas/ } \\
\text { amount of combination of the } \\
\text { environment principals with the } \\
\text { tourism rules and planning. }\end{array}$ & $\mathrm{B}_{6}$ & Rules and regulations & & \\
\hline $\begin{array}{l}\text { Having ADSL per } 1000 \text { people/ } \\
\text { number of cell phones per } 1000 \\
\text { people/ number of electronic } \\
\text { service centres. }\end{array}$ & $\mathrm{B}_{7}$ & $\begin{array}{l}\text { Information } \\
\text { technology level }\end{array}$ & & \\
\hline $\begin{array}{l}\text { Neighbouring with the insecure } \\
\text { countries of the region/ } \\
\text { sanctions/ economic crises. }\end{array}$ & $\mathrm{B}_{1}$ & $\begin{array}{l}\text { Neighbouring } \\
\text { countries }\end{array}$ & \multirow{3}{*}{$\mathrm{A}_{2}$} & \multirow{3}{*}{ 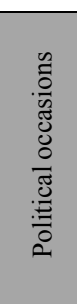 } \\
\hline $\begin{array}{l}\text { Terrorist attacks (11 September)/ } \\
\text { effects of the oil price, etc. }\end{array}$ & $\mathrm{B}_{2}$ & $\begin{array}{l}\text { Occurrence of the } \\
\text { global rises }\end{array}$ & & \\
\hline $\begin{array}{l}\text { Number of the scientific } \\
\text { conferences which are held and } \\
\text { their degree of importance in the } \\
\text { international and regional levels. }\end{array}$ & $\mathrm{B}_{3}$ & Scientific events & & \\
\hline
\end{tabular}


Table 1: $\quad$ Continued.

\begin{tabular}{|c|c|c|c|c|}
\hline The Assessment IndeX & $\begin{array}{l}\text { Weight of } \\
\text { Realms }\end{array}$ & Realms & $\begin{array}{l}\text { Weight of } \\
\text { Classes }\end{array}$ & Class \\
\hline $\begin{array}{l}\text { Number of the sports events } \\
\text { which are held and their degree } \\
\text { of importance in the } \\
\text { international and regional levels. }\end{array}$ & $\mathrm{B}_{4}$ & Sports events & $\mathrm{A}_{2}$ & 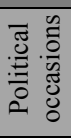 \\
\hline $\begin{array}{l}\text { Number of the attractive public } \\
\text { places of the cities/ number of } \\
\text { the entertaining urban parks/ } \\
\text { number of visits by tourists per } \\
\text { year/ number of artistic and } \\
\text { cultural festivals involving } \\
\text { cinema, music, different kinds of } \\
\text { exhibitions. }\end{array}$ & $\mathrm{B}_{1}$ & Urban attractions & \multirow{3}{*}{$\mathrm{A}_{3}$} & \multirow{3}{*}{ 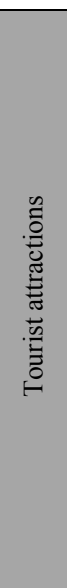 } \\
\hline $\begin{array}{l}\text { Number of cultural or historical } \\
\text { sites/ way of information-giving } \\
\text { of these centres/ number of visits } \\
\text { by tourists per year. }\end{array}$ & $\mathrm{B}_{2}$ & $\begin{array}{l}\text { Historical- cultural } \\
\text { attractions }\end{array}$ & & \\
\hline $\begin{array}{l}\text { Number of the attractive natural } \\
\text { sites equipped with tourist } \\
\text { services/ type of the services } \\
\text { given to the tourists in these } \\
\text { sites/ number of visits by tourists } \\
\text { per year. }\end{array}$ & $\mathrm{B}_{3}$ & Natural attractions & & \\
\hline $\begin{array}{l}\text { Cost of energies consumed in } \\
\text { tourism section/ sum of } \\
\text { employment/ the average income } \\
\text { of the families/ benefiting from } \\
\text { different kinds of services } \\
\text { (water, electricity, gas, telephone, } \\
\text { and internet). }\end{array}$ & $\mathrm{B}_{1}$ & Cost-benefit & \multirow[t]{2}{*}{$\mathrm{A}_{4}$} & \multirow{2}{*}{ 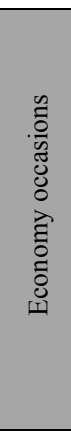 } \\
\hline $\begin{array}{l}\text { Percentage of the direct } \\
\text { investment of tourism by GPD/ } \\
\text { inflation rate/ rate of tourism } \\
\text { profit growth/ rate of profiting } \\
\text { and efficiency in active tourism } \\
\text { institutions. }\end{array}$ & $\mathrm{B}_{2}$ & Investment & & \\
\hline $\begin{array}{l}\text { How people treat and receive the } \\
\text { tourists/ education level/ } \\
\text { familiarity with the international } \\
\text { languages per } 100 \text { people. }\end{array}$ & $\mathrm{B}_{1}$ & $\begin{array}{l}\text { Local culture and } \\
\text { knowledge }\end{array}$ & \multirow{3}{*}{$\mathrm{A}_{5}$} & \multirow{3}{*}{ 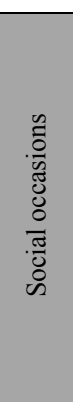 } \\
\hline $\begin{array}{l}\text { Percentage of tourists' } \\
\text { satisfaction from the services. }\end{array}$ & $\mathrm{B}_{2}$ & Degree of satisfaction & & \\
\hline $\begin{array}{l}\text { Number of police centres/ crime } \\
\text { rate per } 100000 \text { people/ number } \\
\text { of police stuff who protect the } \\
\text { environment and supervise the } \\
\text { tourism activities in natural } \\
\text { environments. }\end{array}$ & $\mathrm{B}_{3}$ & Security & & \\
\hline
\end{tabular}


Table 1: $\quad$ Continued.

\begin{tabular}{|c|c|c|c|c|}
\hline The Assessment IndeX & $\begin{array}{l}\text { Weight of } \\
\text { Realms }\end{array}$ & Realms & $\begin{array}{c}\text { Weight of } \\
\text { Classes }\end{array}$ & Class \\
\hline $\begin{array}{l}\text { Number of active NGOs in } \\
\text { tourism and sustainability period/ } \\
\text { number of the active people in the } \\
\text { period of offering tourism } \\
\text { services/ number of the second } \\
\text { houses to rent to the tourists. }\end{array}$ & $\mathrm{B}_{4}$ & participation & $\mathrm{A}_{5}$ & 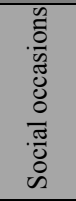 \\
\hline $\begin{array}{l}\text { Sum of different types of sound } \\
\text { pollution, water pollution, soil } \\
\text { pollution and air pollution/ } \\
\text { production of urban trash in } \\
\text { relation with tourism/ energy } \\
\text { consumption in relation with } \\
\text { tourism. }\end{array}$ & $\mathrm{B}_{1}$ & pollution & \multirow{3}{*}{$A_{6}$} & \multirow{3}{*}{ 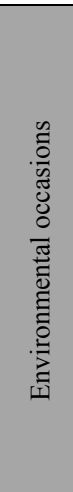 } \\
\hline $\begin{array}{l}\text { Number and depth of dangers } \\
\text { resulting from flood, earthquake, } \\
\text { tsunami, etc. per year. }\end{array}$ & $\mathrm{B}_{2}$ & Natural dangers & & \\
\hline $\begin{array}{l}\text { Number of freezing days per } \\
\text { year/ average temperature of the } \\
\text { environment/ moisture percentage } \\
\text { of the environment. }\end{array}$ & $\mathrm{B}_{3}$ & Weather conditions & & \\
\hline
\end{tabular}

To assess the amount of the sustainable tourism achievement and also to put the determined indices into operation as representative of any class of needs, different methods can be employed the most important of which is using the cumulative linear model. In this model, all the sustainable tourism achievement indices are classified into 6 categories each of which is comprised of several areas. Some of the assessment indices are directed at achieving the sustainable tourism

$$
S T=\sum_{i=1}^{6}\left[\left\{\sum_{j=1}^{n} \alpha_{j}(I V)_{i j}\right\} \times \beta_{i}\right]
$$

$\boldsymbol{S T}=$ sustainable tourism

$\boldsymbol{\alpha}_{\boldsymbol{j}}=$ realm weight $\mathrm{j}$ in intended class i, proportionate to other realms of the same class

$\boldsymbol{\beta}_{\boldsymbol{i}}=$ class weight

$\boldsymbol{I} \boldsymbol{V}_{i j}=$ index value of realm $\mathrm{j}$ in class $\mathrm{i}$ (This amount is negative for the index values which are contrary to the direction of the sustainable tourism development).

Overall, the assessment indices are divided into two general classes: the abstract indices and the concrete indices. The concrete indices of the sustainable tourism assessment consider the environmentally observable conditions, such as the infrastructures, the number of the tourist service centers, number of freezing days in a year, etc. which possess a quantitative and assessable nature, but the abstract indices are obtained from the questions that the researchers ask people 
and the tourists via the questionnaires about the satisfaction from the given services or other similar questions, and these indices have a qualitative nature.

\section{Analytical study for the master plan of Siwa City, Egypt}

Siwa is an excellent example of taking innovative approaches to integrating sustainability in their overall tourism planning and management. In order to better understand the relationship between eco-cities and tourism.

\subsection{Siwa}

The Siwa sits in a depression, as do most of the oases, which today is frequently referred to as the Siwa depression. The depression is 82 kilometers (52 miles) long and between 9 and 28 kilometers wide. The southern parts of the Oasis have succumbed to dunes from the Great Sand Sea, which extends over 500 kilometers north to south and 60 to 80 kilometers east to west. The Siwa sits at the northwest edge of this Great Sand Sea. There are portions of the Siwa Depression that lie as much as 60 meters (192 feet) below sea level, but its average depth is 18 meters below sea level (Figure 1).
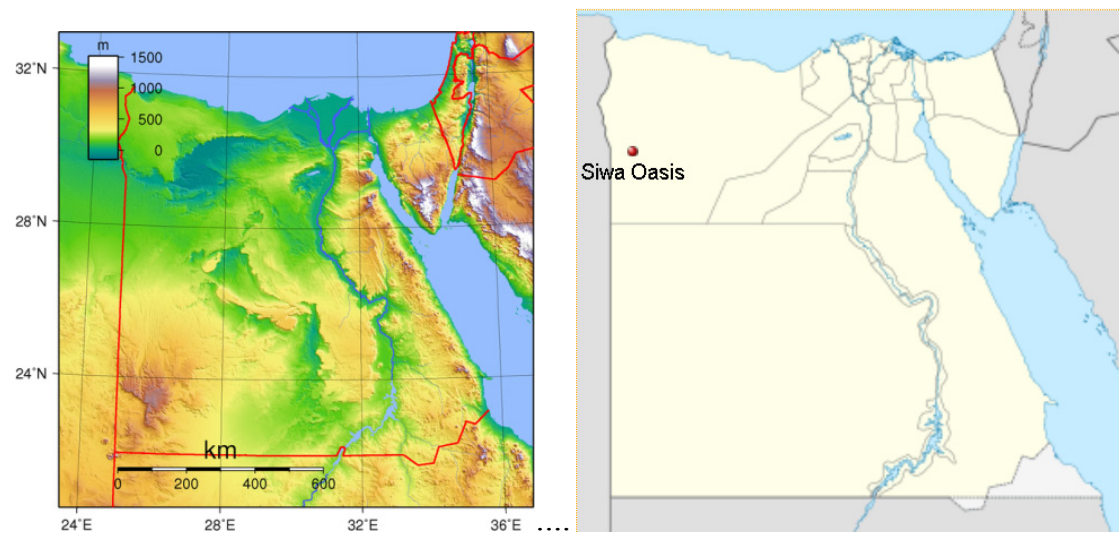

Figure 1: $\quad$ Site of Siwa Oasis in Egypt (top left).

The Siwan people (23,000 people) have their own culture and customs and, as well as speaking Arabic, we speak own Berber (Amazigh) language. Women still wear traditional costumes and silver jewellers and Siwa remains one of the best places to buy traditional local handicrafts [7]. Agriculture is the main activity of modern Siwa [8]. Tourism has in recent decades become a vital source of income.

The climate of Siwa is considered to be continental being very cold in the winter and very hot in the summer and moderate in the spring and autumn. The best timing to visit Siwa is in the spring or the autumn when the weather is nice and there are a lot of festivals and celebration in the city. 
Every two years, Environmental Quality International (EQI) invites an internationally renowned artist or team of artists to design an installation that showcases Siwa's rich culture, history and natural environment, and engages Siwa's schoolchildren in its assembly and exhibition (Siwa web site, 2012).

The 200 year-old annual Spiritual Journey, also known as the Tourist Festival, is a 3-day spiritual and religious Siwan festival that usually coincides with the full moon in October. Through prayer, ritualized feasts and celebrations, the people of Siwa gather to praise God and the Prophet Mohamed, resolve disagreements, harvest dates and olives and perform marriages on the mountain of Gabal al Dakrur, one of the oasis' most awesome natural settings.

The modern town of Siwa is set among thick palm groves, walled gardens and olive orchards, with numerous freshwater springs and salt lakes. Siwa also clusters beneath the impressive remains of the ancient fortress town of Shali (Siwa oasis web site, 2012).

There are many desert paths that lead into and out of the Siwa, but most of them remain inaccessible by modern vehicles. All of these tracks wind through passes in the escarpment, though most are not really clearly visible.

Most people heading to the Siwa probably take the most important route, known as the Masrab Al-Istabl, or Stable Road (touregypt.net) (Figure 2).

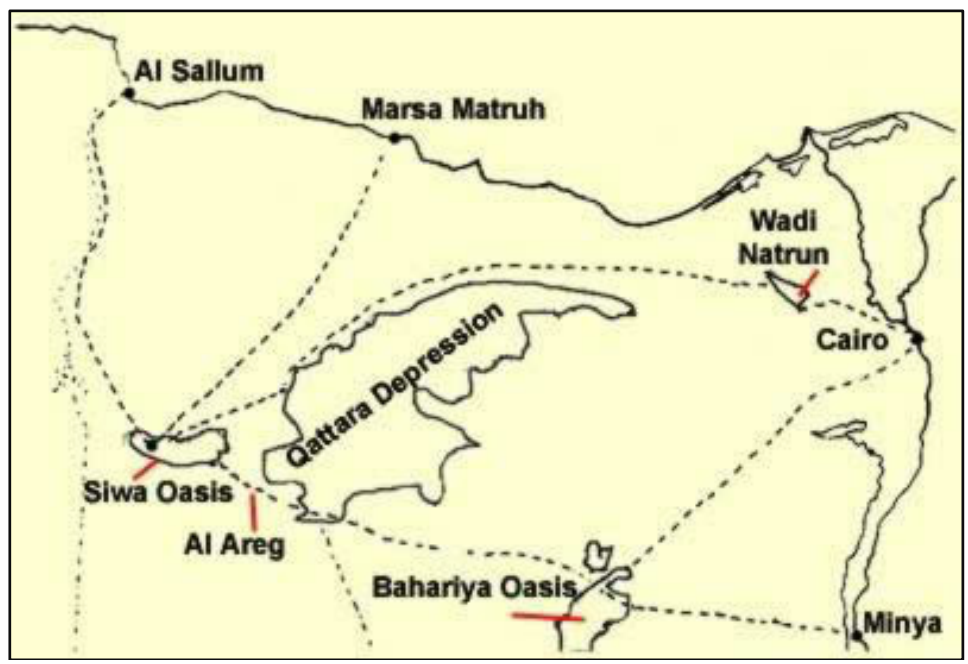

Figure 2: $\quad$ Paths that lead into and out of the Siwa.

\subsection{Siwa eco indices}

- Buildings' walls are built by local craftsmen with kershef, a traditional building material made out of mud, sand, and sun-dried salt harvested from the Siwa's salt lakes. In addition to blending in with the surrounding natural environment, kershef acts as a natural insulator, keeping indoor air temperatures mild in both hot and cold seasons (Figure 3). 


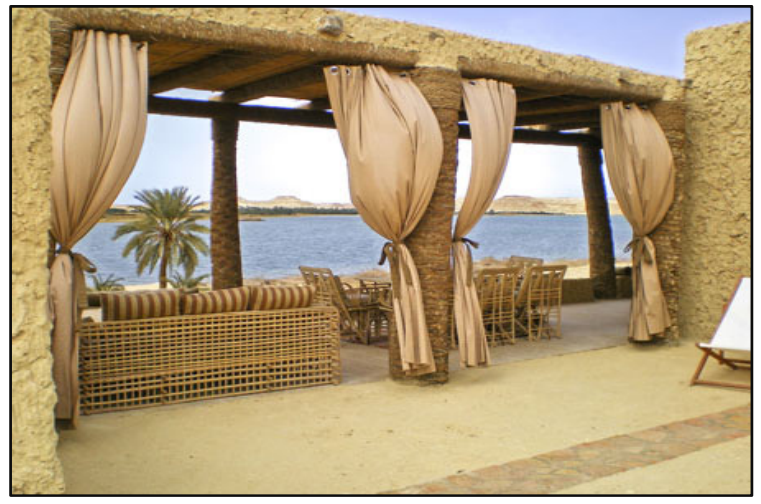

Figure 3: Buildings are constructed from locally-available materials including mud, sun-fired bricks, palm wood, reeds and stone.

- No electricity in the buildings. Niches have been installed within the thick walls in kershef to place candles.

- A spring spurting out in the bottom of the mountain, not very far in the south, irrigates the palm grove and continuously feeds the kitchen and bathrooms with fresh and healthy water, as well as a small pool and the basin at the centre of the buildings intended for cooling the courtyard and adjacent rooms.

- Waste water treatment is ensured with reed grove.

- The tower, master room of the property has a natural air conditioning system using draughts: warm air in the rooms is vented within its two walls for fresh air coming from evaporation of water of the basin in the centre of the courtyard (Figure 4).

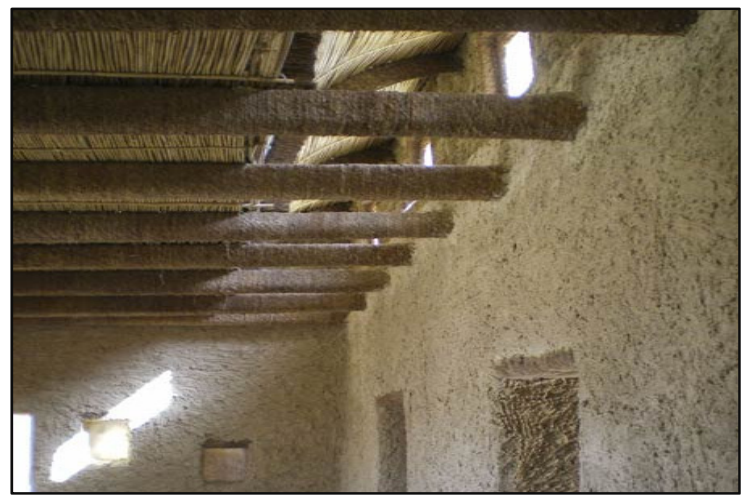

Figure 4: The tower draws air upwards from a water basin to cool the rooms. 


\section{Recommendations for sustainable tourism within an eco-city context}

Managing tourism within an ecosystem context is about a number of dimensions including creating cityscapes and landscapes that are worth the tourist's long journey; sites full of natural and cultural qualities which provide memorable experiences, business practices that protect the environment and contribute to the social, economic and cultural development of the host communities, respect for the environment, protection of local traditions and lifestyles and finally an increased appreciation of a community's history and traditions. This rather formidable list of objectives exemplifies the complexities of sustainability within a tourism environment. Ultimately the objective is to ensure the overall success of the tourism destination within an increasingly competitive visitor landscape.

- The need to map the development of environmentally sustainable planning for the provinces of Egypt, to extract the areas of the establishment of appropriate environmental and construction projects linked to rates of population increase and geographically distributed so as to achieve balance between natural resources available and the needs of key life (Figure 5).

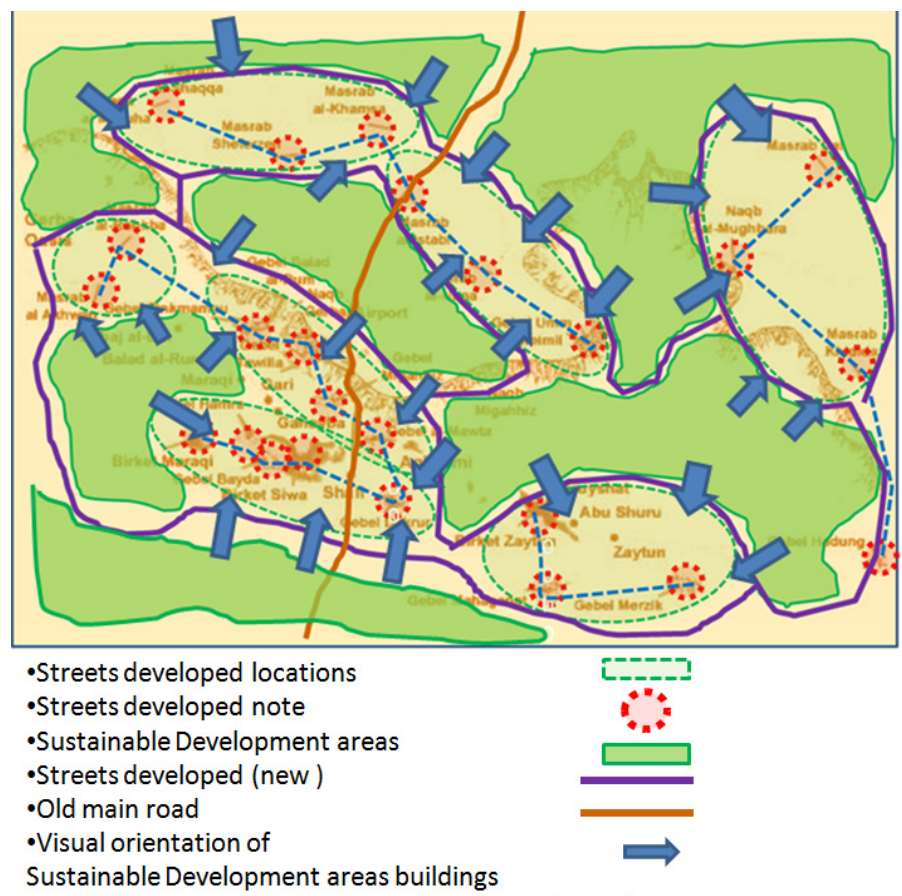

Figure 5: $\quad$ Sustainable touristic master plan of Siwa City. 
- Encourage architectural styles compatible with the design of sustainable saving of natural resources (water - energy - materials) and nondependent on non-renewable resources and treatment of contaminated environmental outcomes by reducing the losses of environmental and waste recycling.

- Encourage technology implementation style treatment of the physical environmental effects as one of the techniques used to maintain the environmental sustainability of the project depends on urban courses closed (Closed Cycles) and rates of environmental waste.

- Promoting the exploitation of the strong local human expert (design implementation) to participate in the establishment of self-construction projects to achieve the communication between the project and the natural environment and society.

- A point of training and funded the projects of urban collective and individual local centres in the governorates to finance urban development projects in order to encourage environmentally sustainable methods of implementation of the resettlement of distinctive natural environments in Egypt.

- Design a map of the sustainable development of Siwa using the system (GIS) described the quality of the projects proposed and the size and time so as to maintain the rate of substitution and replacement construction projects between the proposed and existing buildings currently.

\section{Conclusion}

Within an eco-city approach the following tourism planning and management dimensions must be considered if destinations are to be sustainable and competitive:

- All the stakeholders in tourism development should safeguard the natural environment with a view to achieving sound, continuous and sustainable economic growth geared to equitably satisfying the needs and aspirations of present and future generations.

- All forms of tourism development that are conducive to saving rare and precious resources, in particular water and energy, as well as avoiding so far as possible waste production, should be given priority and encouraged by national, regional and local public authorities.

- The staggering in time and space of tourist and visitor flows, particularly those resulting from paid leave and school holidays, and a more even distribution of holidays should be sought so as to reduce the pressure of tourism activity on the environment and enhance its beneficial impact on the tourism industry and the local economy.

- Tourism infrastructure should be designed and tourism activities programmed in such a way as to protect the natural heritage composed 
of ecosystems and biodiversity and to preserve endangered species of wildlife. Stakeholders in tourism development, and especially professionals, should agree to the imposition of limitations or constraints on their activities when these are exercised in particularly sensitive areas: desert, polar or high mountain regions, coastal areas, tropical forests or wetlands, nature reserves or protected areas;

- Nature tourism and eco-tourism are recognized as being particularly conducive to enriching and enhancing the reputation of tourism, provided they respect the natural heritage and local populations and are in keeping with the carrying capacity of the sites.

It is hoped that this discussion has helped to introduce another element into the debate and implementation of eco-city principles within the larger process of urban and metropolitan planning and management with a special focus on tourism. This debate is especially important given the growth of tourism in many urban areas not prepared for tourism activity.

\section{References}

[1] Essawy, Faiz (1998) "Study Damujgraveh of the Siwa Oasis - Future Vision" seminar about a new map of Mamour of Egypt, Alexandria, Egypt.

[2] Seminar on eco-friendly city (200 722 - Ministry of State for Environmental Affairs (2002), the executive regulations of the Environmental Law No. 338 of 1995, Cairo, Egypt), Ministry of State for Environmental Affairs, Cairo, Egypt.

[3] Eco-city Planning Policies, Practice and Design, Tai-Chee and Wong Belinda Yuen, Springer Science+Business Media B.V. 2011.

[4] 2011 International Conference on Green Buildings and Sustainable Cities, Assessment the feasibility of sustainable tourism in urban environments employing the cumulative linear model, Hamid Azizi, Mahdi Biglari, and Pouya Joudi.

[5] 2011 International Conference on Green Buildings and Sustainable Cities Ecological, city and urban sustainable development, Yijun Song.

[6] http://www.touregypt.net/featurestories/siwa1.html

[7] "Siwa", Encyclopædia Britannica, 2007.

[8] Elevation data by NASA's SRTM. 